Article

\title{
The Role of Agriculture in Ensuring Food Security in Developing Countries: Considerations in the Context of the Problem of Sustainable Food Production
}

\author{
Karolina Pawlak *(1) and Małgorzata Kołodziejczak \\ Department of Economics and Economic Policy in Agribusiness, Faculty of Economics and Social Sciences, \\ Poznan University of Life Sciences, Wojska Polskiego 28, 60-637 Poznan, Poland; \\ malgorzata.kolodziejczak@up.poznan.pl \\ * Correspondence: karolina.pawlak@up.poznan.pl
}

Received: 30 May 2020; Accepted: 5 July 2020; Published: 7 July 2020

\begin{abstract}
Ensuring food security has become an issue of key importance to countries with different degrees of economic development, while the agricultural sector plays a strategic role in improving food availability. The aim of this paper is to identify relationships between the undernourishment scale and selected characteristics describing the agricultural sector within identified clusters of developing countries. Typological groups of countries were separated using Ward's method. It results from the analyses that the greatest problems with maintaining food security are observed in the developing countries with a high share of agriculture in their Gross Domestic Product (GDP), adverse conditions hindering agricultural production and deficient infrastructure. Based on research results desirable and tailored strategies for food security improvement in individual clusters were developed. Promoting investments in agricultural infrastructure and extension services along with adopting measures aimed at increasing the households' purchasing power, especially those in rural areas, appear to be key drivers for improving both food availability and food access. The paper focuses not only on identifying the reasons of undernourishment, but also contributes to recognition of the most effective ways to solve the hunger problem under a country's unique conditions. It offers a comprehensive perspective for the policy formulation in various areas world-wide, which may be of interest to scholars and policy makers.
\end{abstract}

Keywords: food security; arable land; capital stock; food production; population growth; agri-food trade; developing countries

\section{Introduction}

Despite various measures taken to alleviate the world hunger problem, food insecurity and undernutrition remain serious problems in many countries [1]. Although achieving food security is desirable irrespective of the political system and socioeconomic conditions [2], it is an extremely high priority in the developing regions of the world, where population growth coupled with the increased intensity of such environmental events as floods, droughts, extreme variability in temperature or rainfall often pose a threat to food security [3]. Furthermore, due to greater food demand and reduced crop productivity, higher food prices along with income inequalities may negatively affect food access and availability for poor households. It should be noted here that poverty, war and conflict, natural disasters and climate change, as well as population growth are considered to be the main causes of hunger and malnutrition [4-7]. According to the most recent Food and Agriculture Organization of the United Nations (FAO) data, around 13\% of the population living in developing countries are suffering from undernourishment [8], while Porkka et al. [9] indicated that feeding the 
world's population is a challenge that is likely to become even more serious in the future. The global population exceeded 7.6 billion people in 2018 [10] and is predicted to reach 9.2 billion by 2050 [11], with a projected increased food demand of $59 \%-102 \%$ [12,13]. In view of the above it seems necessary to increase agricultural production by about $60 \%-70 \%$ to provide food for the global population in 2050 [11]. According to Foley et al. [14] and Tilman et al. [15], food production needs to as much as double by 2050 to meet the increasing demand.

The agricultural sector plays a strategic role in improving the availability of food and achieving food security [16-19]. However, while there is general agreement on the increased global demand for food to be expected in the coming decades, there is uncertainty surrounding global agriculture's capacity to service this demand through an expansion in the food supply [20]. Better food provision ensured by increasing the productivity of agriculture and expanding the range of agricultural land use seems to be a possible method to eradicate hunger [21,22]. However, in the case of low-income developing countries the existing technology and knowledge will not enable them to produce all the food needed in 2020 and beyond [23]. It shows the need to expand investments in agricultural research and extension systems both in and for developing countries to increase the productivity of agricultural production per unit of land and per agricultural worker. For Sub-Saharan Africa, it was discussed by Otsuka [17]. Based on these studies [17,23], it can be clearly implied that it is necessary to focus on investments that will push African agriculture toward higher productivity without severe environmental degradation. Technology transfer from developed to developing countries should be facilitated to support these processes, to eliminate technology gaps and to overcome knowledge barriers [15].

Bearing in mind that agriculture has a much greater impact on reducing poverty and improving food security than the other sectors of the economy [24,25], and considering differences in the potential for agricultural production across countries, the aim of this paper is to identify relationships between the undernourishment scale and selected characteristics describing the agricultural sector within identified clusters of developing countries.

Attempts have already been made to recognize groups of countries categorized according to measures of food security. It is shown that different research issues resulting in different sets of measures used in the classification can lead to different typologies and hence different conclusions. For example, Diaz-Bonilla et al. [26] and Diaz-Bonilla and Thomas [27] focused mainly on food availability issues, utilizing consumption, production and trade measures. They stressed that trade policies influence world food availability, as well as food production and food imports at the national level. The indicators used in the study include those describing food availability, access and utilization, i.e., food production per capita, the ratio of total exports to food imports, calorie intake per capita, protein intake per capita and non-agricultural population, while the authors address the key question: what types of countries can use trade and what types of countries can use domestic production to secure food supply? They identify groups of countries with similarities in their food security profiles covering the results of agricultural activity and consumption levels rather than agricultural-based reasons for food insecurity. A similar result-oriented approach was also employed by Baer-Nawrocka and Sadowski [28], who identified the current status of food security in different countries around the world considering jointly both the physical and economic availability of food. Reasons for food insecurity related to the agricultural sector were more specifically considered by Yu et al. [29] or Yu and You [30]. Referring to the study by Diaz-Bonilla et al. [26], apart from variables representing food consumption, production, trade and distribution they included in their factor analysis also the agricultural potential. This dimension of food security was represented by three specific variables, including the length of the growing period, variation in the length of the growing period and soil quality. It may be noticed here that a limitation of those studies stems from the fact that the agricultural potential covers only one production factor, i.e., natural resources. Neither agricultural labor nor capital were taken into account, which makes the analyses less comprehensive. A more specific approach was adopted by Zhang et al. [31], who provided a typology of African countries based on 56 variables in the following data sets: development outcome, 
geography, macroeconomic environment, level of security, governance, natural disasters, social and physical infrastructure, agricultural potential, cultural homogeneity, human disease and other factors. In terms of the agricultural potential, they considered not only land and water related variables, but also the share of arable area under irrigation, while the degree of food insecurity was represented by the percentage of children under five years old, who are undernourished. The prevalence of undernourishment among the adult population was not investigated. More food security indicators and more determinants of food and nutrition security were incorporated by Pieters et al. [32]. However, the agricultural potential and performance are restricted to the length of the growing period, soil quality, precipitation, value added per worker in agriculture, import share of agriculture and food production per capita. Despite the limitations of the above-mentioned studies, some valuable conclusions can be drawn. The results suggest that developing countries are extremely heterogeneous in terms of different aspects of food security, hence different policy interventions are needed by different types of food-insecure countries to improve their nutrition status. Our study attempts to meet this challenge.

The paper focuses on the spatial diversity of undernourishment in the most affected developing countries. We identify groups of countries with similarities in their food security profiles based on the prevalence of undernourishment as a measure of food insecurity and select characteristics describing the agricultural sector that refer to the role of agriculture and the agri-food trade in the national economy or are responsible for the production potential. In this way we examine the linkage between food security, agricultural performance and the potential represented by all basic production factors (land, labor and capital). However, our intention is to contribute not only to the discussion on the reasons for undernourishment, but also to the recognition and better understanding of the most effective ways to solve the hunger problem under a country's unique conditions. Hence, based on research results some desirable and tailored strategies for food security improvement in individual clusters are recommended, while the paper offers a comprehensive perspective for the policy formulation world-wide, which may be of interest to scholars and policy makers. Bearing in mind the most common causes of undernourishment, the potential for food production in countries suffering from undernourishment, as well as the depletion of natural resources and the need to ensure sustainable development, this paper attempts to open a new perspective on opportunities to improve the nutrition situation in the world, while it also provides directions for relevant international policies. What was also noted, was the importance of stimulating socio-economic development processes to overcome barriers that prevent the eradication of hunger (or at least the alleviation of undernourishment). Provided considerations are embedded in a research framework based on the controversies surrounding the Malthusian theory and its implications for the world hunger problem.

\section{Selected Aspects of the World Hunger Problem: Around the Malthusian Theory and a Challenge to Feed the World Sustainably}

In his classification of needs by urgency and intensity, Maslow [33] stated that the need to alleviate hunger and thirst is among the basic needs and is essential for human life. In An Essay on the Principle of Population, As It Affects the Future Improvement of Society, published in 1798, Malthus claimed that the population size grows geometrically, beyond control, while the production of food grows only arithmetically [34]. According to Malthus, if the population grows while the supply of natural resources (especially land) remains constant, productivity in agriculture tends to decline. This results in a situation in which agricultural production is unable to keep up with the growing population, while the reduction in supply is followed by famine. Though fitting the realities of the industrial revolution, the Malthusian theory was quickly met with strong criticism. The primary failure of the Malthusian approach was to miss technological progress enabling food production growth without the need to acquire new land resources. This issue was addressed by Boserup, who found that food production, thanks to innovations and technological progress, was growing faster than the population size (this pattern is referred to as the Boserupian model), thus preventing the Malthusian catastrophe [35]. 
The Malthusian population theory, formulated at the end of the 18th century, has been demonstrated to be largely wrong (see [36,37]; etc.) Furthermore, from the 18th century onwards, food supply has almost always increased faster than the population growth [38]. Nevertheless, the undernourished population is still more than 800 million [39]. Therefore, a question arises concerning the underlying causes. According to Poleman [40], food production has been growing much faster than the world's population, but only in developed countries. This was not the case in developing countries. While the food production volume has also increased in these countries, the growth rate was close to the population growth in most cases. Moreover, it has fluctuated increasingly. Poleman [40] sees the main causes of undernourishment in insufficient incomes. Numerous studies assessing the relationship between income and food consumption reveal the existence of a positive relationship [41-43]. Increasing the households' purchasing power in poorly developed countries as a way to eliminate poverty and improve food security was emphasized by several researchers, including Sen [44]. Engel's law laid the foundations for this discussion when establishing that households' demand for food increases less than proportionally in relation to the increase in income. Therefore, income distribution changes are of key importance when predicting food demand growth. Faster income growth among poorer countries and households should be followed by a more rapid growth in food demand in the short and medium term, due to the fact that as the income of poorer households grows, larger shares of their budget are available for food consumption [41].

Published in 2010, the sixth report on the world nutrition situation by the United Nations System Standing Committee on Nutrition (UNSCN) points to the key role of agriculture in ensuring food and nutrition security [45]. Since the worldwide food production capacity is no longer the main limitation, the problem of exhausting resources and sustainable food production appears. Some scientists observed that intensive and industrialized food production practices, which have been developed to satisfy the global food demand [46], have been increasingly damaging the environment [47] and may bring ecological catastrophe on a local or even global scale. Rockström et al. [48] noted the existence of some bio-physical thresholds in the global ecosystem which, when exceeded, may have disastrous consequences for humankind. Due to environmental pollution and the reduced ecological stability of the biosphere, hundreds of millions of people living in extreme poverty will not have a realistic chance of alleviating hunger and addressing other vital needs. According to Geist and Lambin [49] and Foley et al. [14,50], agriculture is the largest contributor to tropical deforestation and is responsible for up to $35 \%$ of global greenhouse gas emissions, with demonstrated negative impacts on air and water quality, biodiversity, carbon sequestration and infectious disease transmission. On the other hand, it is shown that a more productive and resource-efficient agriculture can increase the availability of food and contribute to world food security, while at the same time preserving natural resources and biodiversity [51-57]. McDonald [58] also followed this finding and stressed that it is a universal observation, especially in developing and the least developed countries, indicating that hunger is widespread with many food production systems being unsustainable. There are several indications that a new orientation for agricultural development must be sought [59-63]. The new trajectory of agricultural development should take into account the postulates of sustainable development in all countries, with special regard afforded to the developing ones. Obviously, some transitional stages, such as replacing human labor with mechanical power (mechanization of agriculture), cannot be completely omitted. However, it should be noted that at such an early stage of development of agricultural production (e.g. in some African countries), some environmental restrictions may emerge. Otherwise, in the future these countries would incur significant costs of today's production growth, especially when it comes to areas threatened by soil degradation and water scarcity.

When observing a progressive deterioration in the global nutrition situation, a challenge to feed the growing world's population becomes more and more important, while the role of efficient and sustainable agriculture in this process seems to be a priority (for more see e.g. [64]). Therefore, in this study selected characteristics of the agricultural sector in developing countries were analyzed as determinants of their food security status. 


\section{Materials and Methods}

The study is based on data from the Statistics Division of the Food and Agriculture Organization of the United Nations (FAO) [65]. The analysis covered 100 developing countries most affected by undernourishment, for which the most recent and comprehensive FAO data from 2016-2018 were available. The comparative analysis method was employed to perform the research. Typological groups of countries were separated based on within-group variability using Ward's agglomerative hierarchical clustering method. According to Wysocki [66], Ward's linkage method is by around $40 \%$ more effective than the next best hierarchical method, i.e., the furthest neighbor method. Ward's method allows for the merging of objects into subsequent clusters based on the value of the similarity function. This leads to the minimization of the sum of squared deviations of any two clusters that may be created at each stage, as per the following formula:

$$
\Delta(A, B)=\sum_{i \in A \cup B}\left\|\vec{x}_{i}-\vec{m}_{A \cup B}\right\|^{2}-\sum_{i \in A}|| \vec{x}_{i}-\vec{m}_{A}||^{2}-\sum_{i \in B}|| \vec{x}_{i}-\vec{m}_{B}||^{2}=\left.\frac{n_{A} n_{B}}{n_{A}+n_{B}}\left|\vec{m}_{A}-\vec{m}_{B}\right|\right|^{2}
$$

where: $\vec{m}_{j}$ is the center of cluster $\mathrm{j}$, nj is the number of points in it and $\Delta$ is called the merging cost of combining clusters A and B [67]. For a broader description of the clustering procedure with the use of the presented formula, see Ward [68].

The greater the similarity between the points, the sooner they will be merged with one another [69]. Clusters are arranged hierarchically so that the clusters of a lower rank are a part of clusters of a higher rank, in accordance with the hierarchy of similarity between the points [70]. Importantly, unlike the clustering methods proposed earlier by Cox [71] and Fisher [72], Ward's method takes into account the similarity with regard to multiple variables (instead of a single variable). The Euclidean distance, which is one of the most common distances used in respect to objects with measurable features [73], was used for clustering purposes. Following the standardization of variables, bearing in mind that the clustering process is primarily determined by mutually uncorrelated features [74], the calculated that indicators were assessed in terms of correlation coefficients. A correlation matrix was created and indicators with a strong or nearly functional correlation (correlation coefficient higher than 0.75 ) were excluded from the analysis [75]. Values of calculated Pearson's linear correlation coefficients between all the characteristics were at most 0.52 .

Based on substantive criteria and following the literature review [31,32,76-83], a set of indicators describing the agricultural sector, while also considered as causes of food insecurity, was selected for the study. All those indicators either refer to the role of agriculture and agri-food trade in the national economy (share of agriculture in GDP, share of agricultural population in the total population, agri-food trade balance per capita) or are responsible for the production potential (arable land per capita, percentage of arable land equipped for irrigation, number of tractors per 1000 ha of arable land, value of net capital stock per 1 ha of arable land). Bearing in mind the Malthusian theory [34], a gap between the food production growth rate and the population growth rate was also included into the analysis. The prevalence of undernourishment as a measure of hunger and severity of food insecurity [84] was taken into account in the classification process as well. Selection of the indicators for the study was limited by formal criteria. The above-mentioned indicators were those, for which comprehensive and internationally comparable data were available. Due to excessive correlation, two characteristics were removed from further analysis. These were the share of agricultural population in the total population and the number of tractors per 1000 ha of arable land. In the next step, a series of attempts was made to check the robustness of the results to the inclusion or exclusion of various indicators. Finally, the typology of countries was developed based on the following characteristics:

- $\quad$ prevalence of undernourishment (\%);

- $\quad$ arable land area per capita (ha);

- $\quad$ share of agriculture in GDP (\%); 
- $\quad$ percentage of arable land equipped for irrigation (\%);

- $\quad$ agri-food trade balance per capita (USD);

- value of net capital stock per 1 ha of arable land (USD)—net capital stock represents the sum of the written-down values of all the fixed assets still in use, which can also be calculated as the difference between gross capital stock and consumption of fixed capital [85];

- the gap between the food production growth rate and the population growth rate (percentage points) - the indicator refers to the difference between the food production growth rate and the population growth rate. To obtain the food production growth rate, the aggregate volume of agricultural production in the years 2015-2017 was divided by the aggregate for the base period 2004-2006 (a 3-year average was used in order to eliminate the impact of random factors such as climatic conditions; in line with the FAO approach [86] the aggregate volume was compiled by multiplying gross production in physical terms by output farm gate prices for a given year and country). The population growth rate was calculated by dividing the average population in the periods 2016-2018 and 2004-2006.

It should be noted here that the set of indicators suggested in the research is a simple, but relatively rarely made attempt to integrate five main approaches to the analysis of food security [76]. In line with the oldest and the most influential food availability approach, which is also known as the Malthusian approach, the balance or imbalance between population and food production growth is included into the analysis. The income-based approach brings into the analysis such variables related to economic growth as Gross Domestic Product (GDP) and income. The basic needs approach refers to the availability approach and the ability to adequately satisfy food consumption needs for a healthy life at all times. That is why the linkage is considered between the prevalence of undernourishment as a measure of food insecurity and both agricultural potential and performance. The entitlement approach developed by Sen [87] is represented by indicators related to agricultural farms' endowments and foreign trade entitlement. The analysis and results discussion is also compatible with the Sustainable Livelihoods (SL) approach.

A hierarchical procedure was employed to group the countries. The agglomerative technique characterized by the development of a tree-like structure was used. It means that at the beginning of the clustering process each country covered by the analysis is a singleton. Countries which are most similar to each other in terms of designated characteristics are progressively grouped into new, increasingly larger clusters. The ultimate goal is to obtain a single cluster covering all analyzed countries [75]. The number of clusters was based on the requirement that the number of separated subsets cannot be excessively high and the subsets themselves need to be properly separated and internally consistent [88]. The characteristic features of each cluster, i.e., the key reasons for undernourishment in countries belonging to a specific cluster, were separated with the use of the measure of differences between the mean values of continuous metric features [66]:

$$
z_{c k(d)}=\frac{\bar{x}_{c k}-\bar{x}_{k}}{s_{k(w)}}(c=1, \ldots, C ; k=1 \ldots, K)
$$

In the formula above, $\bar{x}_{c k}$ is the mean value of feature $k$ in cluster $c ; \bar{x}_{k}$ is the general average value of feature $k$ in a population of $n$ objects; $s_{k(w)}$ is the average within-cluster variability of feature $k$, calculated as follows:

$$
s_{k(w)}=\left[\frac{1}{N-C} \sum_{c=1}^{C}\left(N_{c}-1\right) \cdot s_{c k}^{2}\right]^{\frac{1}{2}}
$$

with $s_{c k}^{2}$ meaning the within-cluster variance in cluster $c(c=1, \ldots, C)$ calculated for feature $k$. It was assumed that if $z_{c k(d)} \in(-2 ; 2)$, there is an average intensity of feature $k$ in cluster $c$; the feature does not stand out and is not characteristic. If $z_{c k(d)} \in(-3 ;-2\rangle$ or $z_{c k(d)} \in\langle 2 ; 3)$, there is, respectively, a low or high intensity of feature $k$ in cluster $c$; the feature stands out (positively or negatively) and is a 
characteristic feature. In turn, if $z_{c k(d)} \in(-\infty ;-3\rangle$ or $z_{c k(d)} \in\langle 3 ; \infty)$, there is, respectively, a very low or very high intensity of feature $k$ in cluster $c$; the feature stands out (positively or negatively) and is a highly characteristic feature [66].

\section{Results and Discussion}

Ward's method allowed us to separate eleven internally homogeneous clusters of developing countries differing in terms of their population nutrition levels (Figure 1). The mean values of characteristics in specific clusters are shown in Table 1. The measure of differences between mean values, used to identify the characteristic features of specific clusters, is shown in Table 2. Table 3 presents the characteristics of identified clusters of the analyzed countries, while in Table 4 the recommendations on strategies for food security improvement in the identified clusters are included. 


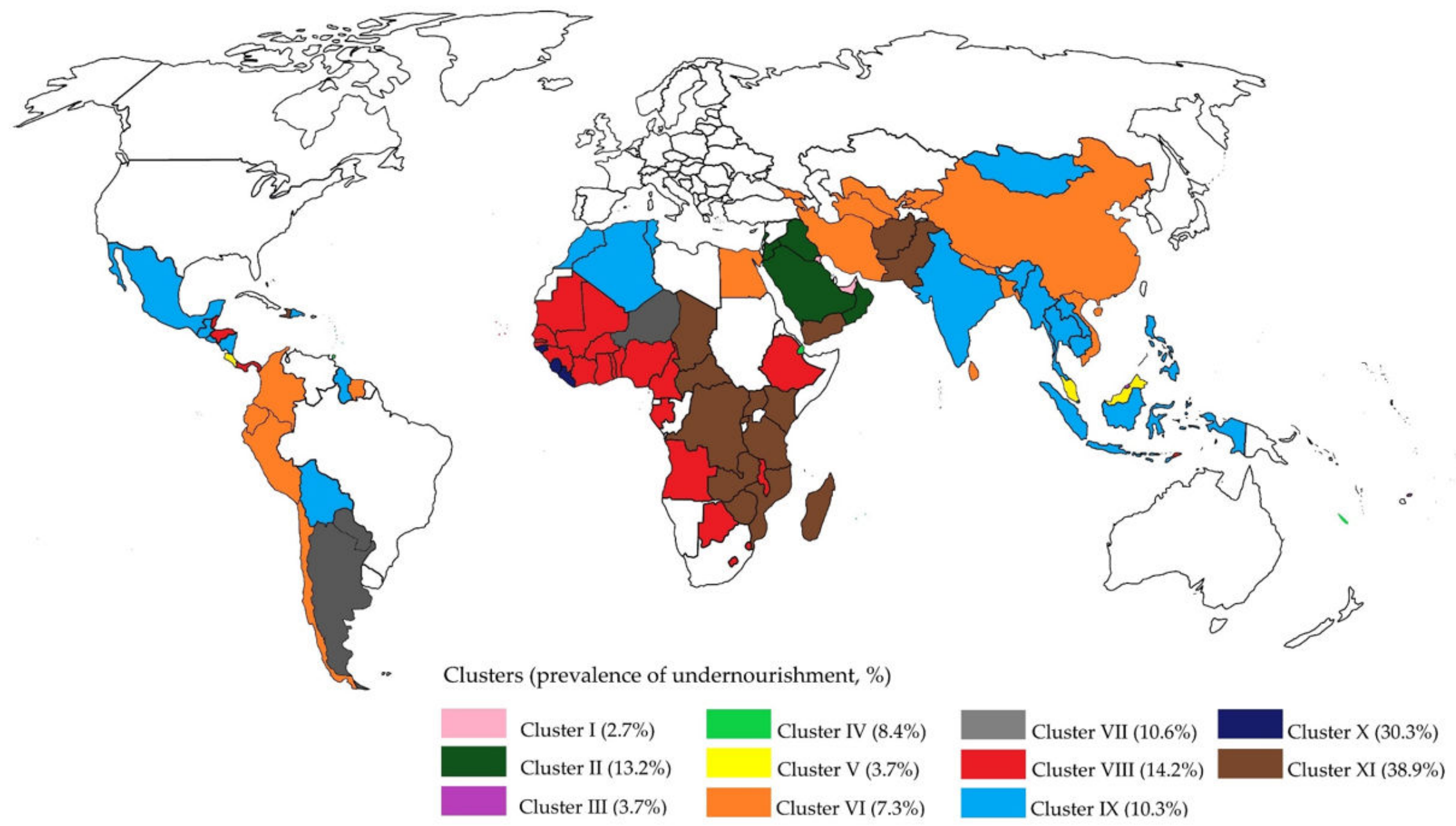

Figure 1. Typology of selected developing countries according to the undernourishment scale and selected characteristics describing the agricultural sector. Source: the authors' calculations based on $[10,39,85,86,89-91]$. 
Table 1. Within-cluster mean values of the undernourishment scale and selected characteristics describing the agricultural sector in the set of developing countries.

\begin{tabular}{|c|c|c|c|c|c|c|c|c|c|c|c|c|}
\hline \multirow{2}{*}{ Feature } & \multicolumn{11}{|c|}{ Cluster } & \multirow{2}{*}{ Average } \\
\hline & $\mathbf{I}$ & II & III & IV & $\mathbf{V}$ & VI & VII & VIII & IX & $x$ & XI & \\
\hline Prevalence of undernourishment (\%) & 2.7 & 13.2 & 3.7 & 8.4 & 3.7 & 7.3 & 10.6 & 14.2 & 10.3 & 30.3 & 38.9 & 13.0 \\
\hline Arable land per capita (ha) & 0.003 & 0.057 & 0.010 & 0.024 & 0.038 & 0.103 & 0.792 & 0.183 & 0.182 & 0.155 & 0.178 & 0.157 \\
\hline Share of agriculture in GDP (\%) & 0.6 & 3.0 & 1.9 & 1.6 & 6.1 & 11.6 & 18.2 & 15.7 & 11.7 & 63.2 & 21.7 & 14.1 \\
\hline $\begin{array}{c}\text { Percentage of arable land equipped for } \\
\text { irrigation }(\%)\end{array}$ & 100.0 & 76.3 & 30.0 & 53.6 & 47.4 & 79.6 & 3.2 & 4.9 & 22.8 & 3.6 & 14.7 & 39.6 \\
\hline Agri-food trade balance per capita (USD) & -1159.3 & -371.3 & -1092.9 & -747.3 & 399.0 & -19.2 & 431.8 & -55.7 & -15.3 & -5.8 & -24.5 & -241.9 \\
\hline $\begin{array}{c}\text { Value of net capital stock per } 1 \text { ha of } \\
\text { arable land (USD) }\end{array}$ & $76,530.4$ & 8480.2 & $60,019.0$ & $11,771.3$ & $56,726.0$ & 5352.2 & 859.9 & 1772.6 & 4472.7 & 794.3 & 3146.3 & $20,902.3$ \\
\hline $\begin{array}{l}\text { Gap between the food production } \\
\text { growth rate and the population growth } \\
\text { rate (percentage points) }\end{array}$ & -158.2 & -121.3 & -20.6 & -56.6 & -49.6 & -39.2 & -50.2 & -73.4 & -36.5 & -67.2 & -75.4 & -68.0 \\
\hline
\end{tabular}

Source: the authors' calculations based on [10,39,85,86,89-91].

Table 2. Values of measure of differences between means of characteristics describing the agricultural sector and the undernourishment scale in the set of selected developing countries and clusters (Ward's method).

\begin{tabular}{|c|c|c|c|c|c|c|c|c|c|c|c|}
\hline \multirow{2}{*}{ Feature } & \multicolumn{11}{|c|}{ Cluster } \\
\hline & $\mathbf{I}$ & II & III & IV & $\mathbf{V}$ & VI & VII & VIII & IX & $X$ & XI \\
\hline Prevalence of undernourishment (\%) & -2.30 & 0.04 & -2.08 & -1.03 & -2.09 & -1.27 & -0.54 & 0.25 & -0.60 & 3.84 & 5.77 \\
\hline Arable land per capita (ha) & -2.88 & -1.87 & -2.75 & -2.48 & -2.22 & -1.02 & 11.90 & 0.49 & 0.47 & -0.03 & 0.39 \\
\hline Share of agriculture in GDP (\%) & -2.93 & -2.41 & -2.65 & -2.71 & -1.75 & -0.56 & 0.89 & 0.34 & -0.52 & 10.64 & 1.65 \\
\hline Percentage of arable land equipped for irrigation (\%) & 4.96 & 3.01 & -0.79 & 1.15 & 0.63 & 3.29 & -3.00 & -2.86 & -1.38 & -2.96 & -2.05 \\
\hline Agri-food trade balance per capita (USD) & -7.88 & -1.11 & -7.31 & -4.34 & 5.51 & 1.91 & 5.79 & 1.60 & 1.95 & 2.03 & 1.87 \\
\hline Value of net capital stock per 1 ha of arable land (USD) & 9.73 & -2.17 & 6.84 & -1.60 & 6.27 & -2.72 & -3.51 & -3.35 & -2.87 & -3.52 & -3.11 \\
\hline $\begin{array}{l}\text { Gap between the food production growth rate and the } \\
\text { population growth rate (percentage points) }\end{array}$ & -8.05 & -4.76 & 4.23 & 1.02 & 1.64 & 2.58 & 1.59 & -0.48 & 2.81 & 0.07 & -0.66 \\
\hline
\end{tabular}

Note: grey cells refer to the features that stand out (positively or negatively) and are characteristic to cluster c; white cells refer to the features that do not stand out and are not characteristic

to cluster c. Source: the authors' calculations based on Table 1. 
Table 3. Description of clusters of developing countries according to the undernourishment scale and selected characteristics describing the agricultural sector.

\begin{tabular}{|c|c|c|c|c|c|c|c|c|c|c|c|}
\hline \multirow{2}{*}{ Feature } & \multicolumn{11}{|c|}{ Cluster } \\
\hline & I & II & III & IV & $\mathbf{V}$ & VI & VII & VIII & IX & $X$ & $\mathbf{X I}$ \\
\hline Number of countries & 2 & 5 & 2 & 5 & 2 & 18 & 3 & 25 & 20 & 3 & 15 \\
\hline Prevalence of undernourishment (\%) & - & & & & - & & & & & ++ & ++ \\
\hline Arable land per capita (ha) & - & & - & - & - & & ++ & & & & \\
\hline Share of agriculture in GDP (\%) & - & - & - & - & & & & & & ++ & \\
\hline Percentage of arable land equipped for irrigation (\%) & ++ & ++ & & & & ++ & -- & - & & - & - \\
\hline Agri-food trade balance per capita (USD) & -- & & -- & -- & ++ & & ++ & & & + & \\
\hline Value of net capital stock per 1 ha of arable land (USD) & ++ & - & ++ & & ++ & - & -- & -- & - & -- & -- \\
\hline $\begin{array}{l}\text { Gap between the food production growth rate and the } \\
\text { population growth rate (percentage points) }\end{array}$ & - & - & ++ & & & + & & & + & & \\
\hline
\end{tabular}

grow th rate (percentage points)

Note: grey cells refer to the features that stand out (positively or negatively) and are characteristic to cluster c; empty cells refer to the features that are not characteristic to cluster c; ++ refer

to very high intensity of feature $\mathrm{k}$ in cluster $\mathrm{c}$; + refers to high intensity of feature k in cluster c; - refers to low intensity of feature $\mathrm{k}$ in cluster c; - - refer to very low intensity of feature k in cluster c. Source: the authors' elaboration based on Figure 1 and Table 2. 
Table 4. Recommendations on strategies for food security improvement in identified clusters.

\begin{tabular}{|c|c|c|c|c|c|c|c|c|c|c|c|c|}
\hline \multirow{2}{*}{ Cluster } & \multirow{2}{*}{ Countries } & \multicolumn{11}{|c|}{ Improvement Strategies } \\
\hline & & 1 & 2 & 3 & 4 & 5 & 6 & 7 & 8 & 9 & 10 & 11 \\
\hline I & United Arab Emirates, Kuwait & $x$ & $x$ & & & & & & $x$ & $x$ & $x$ & \\
\hline II & Oman, Saudi Arabia, Lebanon, Jordan, Iraq & $x$ & $x$ & & & & $x$ & & & $x$ & & $x$ \\
\hline III & French Polynesia, Brunei Darussalam & $x$ & & $x$ & $x$ & $x$ & & & & & $x$ & \\
\hline IV & New Caledonia, Trinidad and Tobago, Mauritius, Djibouti, Barbados & $x$ & & $x$ & & $x$ & & & & $x$ & & $\mathrm{X}$ \\
\hline $\mathrm{V}$ & Malaysia, Costa Rica & & & & $\mathrm{X}$ & & & $x$ & $\mathrm{X}$ & $x$ & & \\
\hline VI & $\begin{array}{l}\text { Turkmenistan, Kyrgyzstan, Iran, Suriname, Georgia, Sao Tome and } \\
\text { Principe, Egypt, Ecuador, Chile, Uzbekistan, Nepal, Colombia, } \\
\text { Sri Lanka, China, Peru, Vietnam, Bangladesh, Armenia }\end{array}$ & $x$ & & & & $x$ & & $x$ & & $x$ & & $x$ \\
\hline VII & Niger, Paraguay, Argentina & & & & & $x$ & $x$ & & & & & $x$ \\
\hline VIII & $\begin{array}{l}\text { Mauritania, Gambia, Nigeria, Malawi, Ethiopia, Mali, Togo, } \\
\text { Burkina Faso, Senegal, Guinea, Cameroon, Benin, Ghana, Fiji, Belize, } \\
\text { Gabon, Lesotho, Panama, Cabo Verde, Honduras, Eswatini, } \\
\text { Cote d'Ivoire, Botswana, Timor-Leste, Angola }\end{array}$ & & & & & $x$ & $x$ & & & & & $x$ \\
\hline IX & $\begin{array}{c}\text { Lao People's Democratic Republic, Myanmar, Cambodia, Guyana, } \\
\text { Thailand, Nicaragua, Bolivia, Indonesia, India, Philippines, Guatemala, } \\
\text { Jamaica, Dominican Republic, Mongolia, El Salvador, Dominica, } \\
\text { Mexico, Tunisia, Morocco, Algeria }\end{array}$ & & & & & $x$ & $x$ & $x$ & & & & $X$ \\
\hline$x$ & Liberia, Sierra Leone, Guinea-Bissau & & & & & $x$ & $x$ & & & & & $x$ \\
\hline XI & $\begin{array}{c}\text { Haiti, Zimbabwe, Zambia, Congo, Central African Republic, Uganda, } \\
\text { Madagascar, United Republic of Tanzania, Mozambique, Rwanda, } \\
\text { Kenya, Chad, Yemen, Pakistan, Afghanistan }\end{array}$ & & & & & $x$ & $x$ & & & $x$ & & $x$ \\
\hline
\end{tabular}


Cluster I-countries with the lowest prevalence of undernourishment in the investigated population of countries-was composed of the United Arab Emirates and Kuwait. Compared to the other countries they were distinguished by the lowest share of agriculture in GDP and a very low food production growth rate, which failed to offset the population growth. The volume of agricultural production obtained from the very small area of land suitable for cultivation, despite being fully equipped with irrigation infrastructure and a very high value of net capital stock, was insufficient in relation to existing needs. A significant role in the reduction of undernourishment in those countries was played by food imports. Deficit in the agri-food trade per capita was the highest in that group and amounted to almost USD 1160, i.e., it was almost five-fold higher than the mean for the whole investigated population of countries. The positive and statistically significant effect of trade openness on the level of food security was shown, e.g., by Brooks and Matthews [81] and Dithmer and Abdulai [104]. In relation to the importance of agri-food trade to ensure food security it may also be stated that over $\frac{3}{4}$ countries worldwide (77\%) suffer from calorie deficit [105], while almost $\frac{1}{4}$ of global food production is subject to international trade. Fader et al. [106] indicated that $16 \%$ of the global population consume food provided by international exchange, with the greatest dependency on imports found in countries of North Africa, the Andean countries and the Arab countries.

A more serious problem with ensuring food security than that in cluster I was recorded in the second cluster. It comprises oil exporters, with a marginal role of agriculture in their GDP; countries, in which on average every eighth inhabitant faced undernourishment. At very low, although to a considerable extent irrigated, arable land resources and a relatively low net capital stock per 1 ha arable land, the nutrition status in that cluster was also determined by the potential to obtained imported food products. A considerable role of trade to modify the nutrition status of the local population was also observed in clusters III and IV. They comprised countries which financed imports of food products to eliminate the deficits mainly through exploitation and the processing of crude oil and natural gas (Brunei Darussalam, Trinidad and Tobago), tourism (French Polynesia, New Caledonia, Mauritius, Barbados) or transport services and transit fees (Djibuti). Based on the above results, it may be stated that a crucial role in ensuring food security in countries covered by clusters I-IV is played by trade policies aimed at enhancing trade openness (Table 4). In the Arab countries (clusters I and II) they should have been supplemented by the adoption of innovative technologies to boost food production, delivering services for agriculture, as well as technical, administrative and training support for farmers. In countries classified in clusters III and IV, apart for the liberal trade policy, a milestone to improve the food security status might be to maximize agricultural land use and to develop both farming technologies and investments in agricultural infrastructure.

An approximately 3.5-fold lower prevalence of undernourishment than the average in the developing countries, at a simultaneously high surplus in agri-food trade per capita, was recorded in cluster V. In Malesia and Costa Rica, apart from tourism, an important branch of the national economy is agriculture. Malesia is one of the main world exporters of palm oil, while Costa Rica specializes in the export of pineapples, bananas, coffee and sugar [91]. In these countries, technology transfer and productivity enhancement through implementation of high-yielding varieties and increasing the cropping intensity seem to be important in improving food availability (Table 4). The adaptation and delivery of efficient services, as well as the promotion of training and extension services, might also be desirable to increase agricultural productivity and consequently reduce the undernourishment scale.

Cluster VI comprises 18 countries, in which the prevalence of undernourishment was approximately 2 -fold lower than the average in the developing countries (7.3\% vs $13.0 \%)$. A factor supporting fight against hunger, at a relatively low arable land area per capita, was connected with the scale of irrigation in arable land. It may be observed that the lack of agricultural land and insufficient water resources are the most frequently mentioned causes for a lack of food security indicated in literature on the subject [83], while Gohar, Amer and Ward [82] considered relationships between water availability and irrigation infrastructure and food security. Attaining food security in the cluster including some of the most populous countries in the world (China, Egypt, Bangladesh and 
Vietnam), was in turn hindered by the relatively low net capital stock per 1 ha arable land. As a consequence, the food production growth rate was lower than the population growth rate. A lack of capital stock and investments may be considered as the factor that hampered reaching a higher agricultural performance. It can be noted here that the importance of irrigation infrastructure and the availability of technical production assets to food security in developing countries was indicated by Dec et al. [107]. The impact of new techniques and technologies on farm productivity was also discussed by Schultz [108], Hayami [109], Hayami and Ruttan [110], as well as Stellmacher and Kelboro [111]. In view of the above, all the possible strategies related to the investment in infrastructure and agricultural research, as well as the improvement in extension services and training programs for farmers, seem to be highly recommended to boost agricultural production, while domestic production might be supported by food imports under preferential trade agreements (Table 4). Considering income inequalities in the countries included in this cluster the government policies aimed at increasing the households' purchasing power would also be of key importance to address the food security challenge efficiently.

Cluster VII included three countries obtaining a considerable surplus in agri-food trade per capita, in which the highest resources of arable land per capita in the analyzed population of the developing countries compensated for capital and infrastructure deficits, which manifested, e.g., in the very low percentage of arable land equipped for irrigation. The very low value of net capital stock per 1 ha arable land and a lack of irrigation infrastructure also constituted a barrier to the growth of productivity in agriculture in countries of Africa, Asia and Latin America, classified to clusters VIII and IX.

A very high (over $30 \%$ ) prevalence of undernourishment was recorded in the countries comprising cluster X. The observed very high share of the agricultural sector in GDP may be considered as equivalent to the very low level of income for the population working in agriculture, which on the one hand indicates a lack of resources for investment in farms, while on the other hand-a lack of purchasing power of consumers. The strictly agricultural character of the national economies in those countries compounded problems with providing adequate nutrition to the population. The very low level of capital resources, including a lack of irrigation systems, influenced the level and growth rate in agricultural production, which was insufficient in relation to the population needs, resulting in necessary food imports and a deficit in agri-food trade. It should be stressed here that policy actions aimed at enhancing agricultural productivity, including the development of relevant infrastructure, will not solve the hunger problem without eliminating poverty and increasing the consumers' economic access to food. It strongly refers to the agricultural countries gathered in cluster $X$, but it is also true for clusters VII-IX and XI (Table 4).

The highest prevalence of undernourishment in the analyzed population of countries was found in cluster XI. It consisted of 15 countries (eleven African countries, three countries from Asia and Haiti), in which, similarly as in clusters VIII and IX, despite the relatively large arable land area per capita, the lack of capital and infrastructure led to food shortages suffered by almost $40 \%$ of their inhabitants. Results obtained in the present study confirmed that investment is one of the key drivers for the improvement of efficiency in agriculture and food production. These findings have policy implications for strengthening food security through an increase in efficiency. It has already been emphasized by Ogundari [112], who suggested the need for programs and policies that will boost agricultural efficiency levels through the improvement of extension services, as well as the introduction of robust training programs for farmers on the usage of modern technologies, etc. This issue has also been discussed by Prus [113-115].

\section{Conclusions}

The world experiences highly uneven patterns of socio-economic development, which on one hand are manifested in large surpluses and, on the other, by permanent food shortages contributing to hunger and undernourishment. Maintaining food security is a problem that most severely affects developing countries with low per capita GDP levels, which usually also suffer from unfavorable 
agricultural conditions and infrastructure deficiencies. Based on the cluster analysis, two main reasons for food insecurity may be identified. In some regions, the reason is the physical and/or economic unavailability of food (clusters composed of Sub-Saharan Africa and South-Eastern Asia). Other ones, in turn, experience social inequalities in nutrition (countries affected by this problem include oil producers with various economic development levels, located in different continents, such as Iraq, Angola, Nigeria or Ecuador).

It results from these analyses that problems with maintaining food security are found with the greatest intensity in developing countries with a high share of agriculture in their GDP, adverse conditions hindering agricultural production and deficient infrastructure. However, a small arable area per capita does not necessarily mean high rates of undernourishment. This is because the limited resources of agricultural land may be compensated for by increased productivity and imported food to cover the deficiency. Therefore, somewhat in spite of the Malthusian theory, the irrigation of arable land, the agricultural trade balance and the deployment of technical production assets proves to be more important in determining the nutrition situation than arable area per capita. Increasing the agricultural productivity through the adaptation and adoption of farming technologies, as well as the improvement in extension services and training programs for farmers and implementing an open trade policy which, while not detrimental to the interests of domestic producers and consumers, allows countries to raise funds for financing the import of food that compensates for the short domestic supply. These are the measures that could result in solving the nutrition problem in oil- or natural gas-producing countries and small island tourist economies (clusters I-IV). Promoting environmentally friendly technologies, expanding investments in agricultural research and extension systems and enhancing farmers' education accompanied by technology transfer from developed countries should be seen as crucial components of policies implemented to improve food security in countries facing the challenge of agricultural productivity enhancement, including the most populous ones in the world (clusters V-VI). Investments in agricultural infrastructure along with eliminating income inequalities by adopting measures aimed at increasing the households' purchasing power, especially those in rural areas, are key drivers for improving food access in countries all over the world, with special regard to Africa, Asia and Latin America (clusters VI-XI).

Note that poorly developed countries may lack incentives that trigger growth and agricultural performance, both on the supply and the demand side. With this in mind, and considering Nurkse's model of the vicious circle of poverty [116] and the scarcity of capital, it should be emphasized that alleviating the global hunger problem requires the involvement of the international community, which should provide development assistance oriented at the reasons (rather than just on the effects) for food insecurity. Food aid that supports the development of production and enhancing market infrastructure can play a positive role in enhancing food security. However, food aid is not the only, or in many cases the most efficient, means of addressing food insecurity. In this context, it becomes necessary for developing countries to establish and implement socio-economic growth strategies focused on ensuring conditions for development resulting in increasing the efficiency of national economies, as well as improving the quality of human life. It is necessary to take into account the environmental, social and economic specificity of each country, as well as its political and institutional conditions. Only sustainable development and, subsequently, economic growth is the way to ensure food security at regional, national and individual household levels.

This paper addressed three issues: the linkage between food security, agricultural potential and agricultural performance, spatial diversity of agriculture-oriented reasons for undernourishment, as well as the recognition and better understanding of the most effective interventions to solve the hunger problem under a country's unique conditions. In this way it was possible to offer a comprehensive perspective for the policy formulation world-wide, which may be of interest to scholars and policy makers. However, the study has its limitations. The primary aim of the typology was to investigate spatial diversity in food security and its sectoral causes. Hence, the study is primarily a static one and generally it does not take into account the variation of these variables over time and 
the source of this variation. It may be important to include indicators of time trends to gain insight into changes in the food security status and evaluate the effectiveness of interventions implemented. Examining the impacts of macroeconomic, institutional and external shocks over time would require additional research. These shocks that affect agricultural activity and disrupt agricultural production include, e.g., price fluctuations, trade policies, political instability, weather conditions, natural disasters and epidemic threats. Variables responsible for the population's purchasing power and shaping the economic access to food should also be considered. Including into the analysis both macro- and mesoeconomic determinants would have offered many more comprehensive foundations to establish multidimensional growth strategies aimed at improving food security. It can also be mentioned that this paper, similarly to the majority of existing studies, is related to food availability and food access rather than the health and nutrition dimension of food security. In the further step of the research, it may be valuable to incorporate into the grouping some criteria related to consumption patterns and food utilization.

Author Contributions: Conceptualization, K.P. and M.K.; methodology, K.P.; formal analysis, K.P. and M.K.; investigation, K.P. and M.K.; resources, K.P. and M.K.; writing-original draft preparation, K.P. and M.K.; writing-review and editing, K.P.; visualization, M.K.; supervision, K.P.; project administration, K.P.; funding acquisition, K.P. and M.K. All authors have read and agreed to the published version of the manuscript.

Funding: This research was funded by the Faculty of Economics and Social Sciences, Poznań University of Life Sciences.

Conflicts of Interest: The authors declare no conflict of interest.

\section{References}

1. Sibhatu, K.T.; Qaim, M. Rural food security, subsistence agriculture, and seasonality. PLoS ONE 2017, 12, e0186406. [CrossRef] [PubMed]

2. Jerzak, M.A.; Śmiglak-Krajewska, M. Globalization of the Market for Vegetable Protein Feed and Its Impact on Sustainable Agricultural Development and Food Security in EU Countries Illustrated by the Example of Poland. Sustainability 2020, 12, 888. [CrossRef]

3. Ahmed, U.I.; Ying, L.; Bashir, M.K.; Abid, M.; Zulfigar, F. Status and determinants of small farming households' food security and role of market access in enhancing food security in rural Pakistan. PLoS ONE 2017, 12, e0185466. [CrossRef] [PubMed]

4. Prosekov, A.Y.; Ivanova, S.A. Food security: The challenge of the present. Geoforum 2018, 91, 73-77. [CrossRef]

5. The Top 10 Causes of World Hunger. 27 May 2019. Available online: https://www.concernusa.org/story/topcauses-world-hunger/ (accessed on 20 June 2020).

6. Causes and Effects of Food Insecurity Environmental Sciences Essay. 5 December 2016. Available online: https://www.ukessays.com/essays/environmental-sciences/causes-and-effects-of-foodinsecurity-environmental-sciences-essay.php (accessed on 20 June 2020).

7. Smith, L.C.; El Obeid, A.E.; Jensen, H.H. The Geography and Causes of Food Insecurity in Developing Countries. Agric. Econ. 2000, 22, 199-215. [CrossRef]

8. Our World in Data. Available online: https://ourworldindata.org/hunger-and-undernourishment\#whatshare-of-people-are-undernourished (accessed on 22 May 2020).

9. Porkka, M.; Kummu, M.; Siebert, S.; Varis, O. From Food Insufficiency towards Trade Dependency: A Historical Analysis of Global Food Availability. PLoS ONE 2013, 8, e82714. [CrossRef] [PubMed]

10. Food and Agriculture Organization of the United Nations Statistical Database. Annual Population. Available online: http://www.fao.org/faostat/en/\#data/OA (accessed on 22 May 2020).

11. Silva, G. Feeding the World in 2050 and Beyond-Part 1: Productivity Challenges. Michigan State University Extension-3 December 2018. Available online: https://www.canr.msu.edu/news/feeding-the-world-in-2050and-beyond-part-1 (accessed on 20 June 2020).

12. Elferink, M.; Schierhorn, F. Global Demand for Food Is Rising. Can We Meet It? Harvard Business Review-7 April 2016. Available online: https://hbr.org/2016/04/global-demand-for-food-is-rising-can-wemeet-it (accessed on 20 June 2020). 
13. Fukase, E.; Martin, W.J. Economic Growth, Convergence, and World Food Demand and Supply; Policy Research Working Paper 8257; World Bank Group, Development Research Group Agriculture and Rural Development Team: Washington, DC, USA, 2017.

14. Foley, J.A.; Ramankutty, N.; Brauman, K.A.; Cassidy, E.S.; Gerber, J.S.; Johnston, M.; Mueller, N.D.; O'Connell, C.; Ray, D.K.; West, P.C.; et al. Solutions for a Cultivated Planet. Nature 2011, 478, 337-342. [CrossRef]

15. Tilman, D.; Balzer, C.; Hill, J.; Befort, B.L. Global food demand and the sustainable intensification of agriculture. Proc. Natl. Acad. Sci. USA 2011, 108, 20260-20264. [CrossRef]

16. Smutka, L.; Steininger, M.; Miffek, O. World agricultural production and consumption. Agris on-line Papers Econ. Inform. 2009, 1, 3-12.

17. Otsuka, K. Food insecurity, income inequality, and the changing comparative advantage in world agriculture. Agric. Econ. 2013, 44, 7-18. [CrossRef]

18. Smutka, L.; Steininger, M.; Maitah, M.; Škubna, O. The Czech Agrarian Foreign Trade-Ten Years after the EU Accession. In Agrarian Perspectives XXIV: Proceedings of the 24th International Scientific Conference, Czech University of Life Sciences Prague, Faculty of Economics and Management, Prague, Czech Republic, 16-18 September 2015; Smutka, L., Řezbová, H., Eds.; CAB Direct: Glasgow, UK, 2015; pp. 385-392.

19. Wegren, S.K.; Elvestad, C. Russia's food self-sufficiency and food security: An assessment. Post Communist Econ. 2018, 30, 565-587. [CrossRef]

20. Cook, D.C.; Fraser, R.W.; Paini, D.R.; Warden, A.C.; Lonsdale, W.M.; De Barro, P.J. Biosecurity and Yield Improvement Technologies Are Strategic Complements in the Fight against Food Insecurity. PLoS ONE 2011, 6, e26084. [CrossRef] [PubMed]

21. Stocking, M.A. Tropical Soils and Food Security: The Next 50 Years. Science 2003, 302, 1356-1359. [CrossRef] [PubMed]

22. Smyth, S.J.; Phillips, P.W.B.; Kerr, W.A. Food security and the evaluation of risk. Glob. Food Secur. 2015, 4, 16-23. [CrossRef]

23. Pinstrup-Andersen, P.; Pandya-Lorch, R. Food security and sustainable use of natural resources: A 2020 Vision. Ecol. Econ. 1998, 26, 1-10. [CrossRef]

24. Irz, X.; Lin, L.; Thirtle, C.; Wiggins, S. Agricultural Productivity Growth and Poverty Alleviation. Dev. Policy Rev. 2001, 19, 449-466. [CrossRef]

25. Majid, N. Reaching Millennium Goals: How Well Does Agricultural Productivity Growth Reduce Poverty? Employment Strategy Paper No. 12; International Labour Organization: Geneva, Switzerland, 2004.

26. Diaz-Bonilla, E.; Thomas, M.; Robinson, S.; Cattaneo, A. Food Security and Trade Negotiations in the World Trade Organization: A Cluster Analysis of Country Groups; TMD Discussion Paper No. 59; Trade and Macroeconomic Division, International Food Policy Research Institute: Washington, DC, USA, 2000.

27. Diaz-Bonilla, E.; Thomas, M. Why Some Are More Equal Than Others? Country Typologies of Food Security; Background Paper Prepared for The State of Agricultural Commodity Markets 2015-16; FAO: Rome, Italy, 2015.

28. Baer-Nawrocka, A.; Sadowski, A. Food Security and Food Self-Sufficiency Around the World: A Typology of Countries. PLoS ONE 2019, 14, e0213448. [CrossRef]

29. Yu, B.; You, L.; Fan, S. Toward a Typology of Food Security in Developing Countries. In IFPRI Discussion Paper 00945. Development Strategy and Governance Division; International Food Policy Research Institute: Washington, DC, USA, 2010.

30. Yu, B.; You, L. A Typology of Food Security in Developing Countries. China Agric. Econ. Rev. 2013, 5, 118-153. [CrossRef]

31. Zhang, X.; Johnson, M.; Resnick, D.; Robinson, S. Cross-Country Typologies and Development Strategies to End Hunger in Africa. In DSGD Discussion Paper No. 8. Development Strategy and Governance Division; International Food Policy Research Institute: Washington, DC, USA, 2004.

32. Pieters, H.; Gerber, N.; Mekonnen, D. Country Typology on The Basis of FNS. In A Typology of Countries Based on FNS Outcomes and Their Agricultural, Economic, Political, Innovation and Infrastructure National Profiles; FOODSECURE Technical Paper No. 2; LEI Wageningen UR: Wageningen, The Netherlands, 2014.

33. Maslow, A. Motivation and Personality, 3rd ed.; Addison-Wesley: New York, NY, USA, 1954.

34. Malthus, T.R. An Essay on the Principle of Population, as It Affects the Future Improvement of Society; Printed for J. Johnson: London, UK, 1798.

35. Boserup, E. Population and Technology; Basil Blackwell: Oxford, UK, 1981. 
36. Smith, K. The Malthusian Controversy; Routledge \& Kegan Paul: London, UK, 1951.

37. Foster, P.; Leathers, H.D. The World Food Problem. Tackling the Causes of Undernutrition in the Third World, 3rd ed.; Lynne Rienner Publishers: Boulder, CO, USA, 1999.

38. Dowd, D. Inequality and the Global Economic Crisis; Pluto Press: London, UK, 2009.

39. Food and Agriculture Organization of the United Nations Statistical Database. Suite of Food Security Indicators. Available online: http://www.fao.org/faostat/en/\#data/FS (accessed on 22 May 2020).

40. Poleman, T.T. Quantifying the nutrition situation in developing countries. Food Res. Inst. Stud. 1981, 18, 1-58.

41. Cirera, X.; Masset, E. Income distribution trends and future food demand. Philos. Trans. R. Soc. B Biol. Sci. 2010, 365, 2821-2834. [CrossRef]

42. Rask, K.J.; Rask, N. Economic development and food production-consumption balance: A growing global challenge. Food Policy 2011, 36, 186-196. [CrossRef]

43. Skoufias, E.; Di Maro, V.; González-Cossío, T.; Ramirez, S.R. Food quality, calories and household income. Appl. Econ. 2011, 43, 4331-4342. [CrossRef]

44. Sen, A. Development as Freedom; Anchor Books: New York, NY, USA, 1999.

45. Progress in Nutrition. In 6th Report on the World Nutrition Situation; The United Nations System Standing Committee on Nutrition: Geneva, Switzerland, 2010.

46. Hazell, P.; Wood, S. Drivers of change in global agriculture. Philos. Trans. R. Soc. B Biol. Sci. 2008, 363, 495-515. [CrossRef] [PubMed]

47. Nellemann, C.; Macdevetta, M.; Manders, T.; Eickhout, B.; Svihus, B.; Prins, A.G.; Kaltenborn, B.P. The Environmental Food Crisis: The Environment's Role in Averting Future Food Crises; A UNEP Rapid Response Assessment; United Nations Environment Programme, GRID-Arendal: Arendal, Norway, 2019; Available online: http://www.grida.no/publications/154 (accessed on 12 May 2020).

48. Rockström, J.; Steffen, W.; Noone, K.; Persson, Å.; Chapin, F.S., III; Lambin, E.F.; Lenton, T.M.; Scheffer, M.; Folke, C.; Schellnhuber, H.J.; et al. A safe operating space for humanity. Nature 2009, 461, 472-475. [CrossRef] [PubMed]

49. Geist, H.J.; Lambin, E.F. Proximate Causes and Underlying Driving Forces of Tropical Deforestation: Tropical forests are disappearing as the result of many pressures, both local and regional, acting in various combinations in different geographical locations. BioScience 2002, 52, 143-150. [CrossRef]

50. Foley, J.A.; DeFries, R.; Asner, G.P.; Barford, C.; Bonan, G.; Carpenter, S.R.; Chapin, F.S.; Coe, M.T.; Daily, G.C.; Gibbs, H.K.; et al. Global Consequences of Land Use. Science 2005, 309, 570-574. [CrossRef]

51. Noleppa, S.; von Witzke, H.; Cartsburg, M. The Social, Economic and Environmental Value of Agricultural Productivity in the European Union. Impacts on Markets and Food Security, Rural Income and Employment, Resource Use, Climate Protection, and Biodiversity HFFA Working Paper No. 3; Humboldt Forum for Food and Agriculture e.V. (HFFA): Berlin, Germany, 2013.

52. Wang, S.L.; Heisey, P.; Schimmelpfennig, D.; Bal, E. Agricultural Productivity Growth in the United States: Measurement, Trends and Drivers. In Economic Research Report 189 from United States Department of Agriculture. Economic Research Service; U.S. Department of Agriculture: Washington, DC, USA, 2015. [CrossRef]

53. Pretty, J.; Toulmin, C.; Williams, S. Sustainable intensification in African agriculture. Int. J. Agric. Sustain. 2011, 9, 5-24. [CrossRef]

54. Lee, D.R. Agricultural Sustainability and Technology Adoption: Issues and Policies for Developing Countries. Am. J. Agric. Econ. 2005, 87, 1325-1334. [CrossRef]

55. Adenle, A.A.; Weding, K.; Azadi, H. Sustainable Agriculture and Food Security in Africa: The Role of Innovative Technologies and International Organizations. Technol. Soc. 2019, 58, 1-17. [CrossRef]

56. Basiago, A.D. Sustainable Development in Indonesia: A Case Study of an Indigenous Regime of Environmental Law and Policy. Int. J. Sustain. Dev. World Ecol. 1995, 2, 199-211. [CrossRef]

57. Zhang, J.; Chen, G.C.; Xing, S.; Shan, Q.; Wang, Y.; Li, Z. Water Shortages and Countermeasures for Sustainable Utilisation in The Context of Climate Change in the Yellow River Delta Region, China. Int. J. Sustain. Dev. World Ecol. 2011, 18, 177-185. [CrossRef]

58. McDonald, B.L. Food Security; Polity Press: Cambridge, UK, 2010.

59. Goodland, R.; Ledec, G. Neoclassical Economics and Principles of Sustainable Development. Ecol. Model. 1987, 38, 19-46. [CrossRef]

60. Pretty, J.N. Participatory Learning for Sustainable Agriculture. World Dev. 1995, 23, 1247-1263. [CrossRef] 
61. Daly, H.E. Ecological Economics and Sustainable Development. Selected Essays of Herman Daly; Edward Elgar: Cheltenham, UK, 2007.

62. Zegar, J.S. Wspótczesne Wyzwania Rolnictwa (Contemporary Challenges of Agriculture); Polish Scientific Publishers: Warsaw, Poland, 2012.

63. Vitunskiene, V.; Dabkiene, V. Framework for assessing the farm relative sustainability: A Lithuanian case study. Agric. Econ. Czech 2016, 62, 134-148. [CrossRef]

64. Conceição, P.; Levine, S.; Lipton, M.; Warren-Rodríguez, A. Toward a food secure future: Ensuring food security for sustainable human development in Sub-Saharan Africa. Food Policy 2016, 60, 1-9. [CrossRef]

65. Food and Agriculture Organization of the United Nations Statistical Database. FAOSTAT. Available online: http://www.fao.org/faostat/en/\#data/ (accessed on 22 May 2020).

66. Wysocki, F. Metody Taksonomiczne w Rozpoznawaniu Typów Ekonomicznych Rolnictwa i Obszarów Wiejskich (Taxonomic Methods to Identify Economic Types of Agriculture and Rural Areas); Poznan University of Life Sciences: Poznań, Poland, 2010.

67. Distances between Clustering, Hierarchical Clustering. 36-350, Data Mining. 14 September 2009. Available online: https://www.stat.cmu.edu/ \{\}cshalizi/350/lectures/08/lecture-08.pdf (accessed on 22 May 2020).

68. Ward, J.H., Jr. Hierarchical Grouping to Optimize an Objective Function. J. Am. Stat. Assoc. 1963, 58, $236-244$. [CrossRef]

69. Sokołowski, A. Metody Stosowane w Data Mining (Data Mining Techniques); StatSoft Polska: Krakow, Poland, 2002; Available online: https://media.statsoft.pl/_old_dnn/downloads/metody_stosowane_w_data_mining. pdf (accessed on 20 May 2020).

70. Marek, T. Analiza Skupień w Badaniach Empirycznych, Metody SAHN (Cluster Analysis in Empirical Research. SAHN Methods); Polish Scientific Publishers: Warsaw, Poland, 1989.

71. Cox, D.R. Note on grouping. J. Am. Stat. Assoc. 1957, 52, 543-547. [CrossRef]

72. Fisher, W.D. On grouping for maximum homogeneity. J. Am. Stat. Assoc. 1958, 53, 789-798. [CrossRef]

73. Mardia, K.V.; Kent, J.T.; Bibby, J.M. Multivariate Analysis; Academic Press: London, UK, 1979.

74. Stanisz, A. Przystępny Kurs Statystyki z Zastosowaniem STATISTICA PL na Przykładach z Medycyny. Tom 3: Analizy Wielowymiarowe (A user-Friendlye Course in Statistics using STATISTICA PL Based on Examples from Medicine. Volume 3: Multivariate Analyses), 1st ed.; Statsoft: Cracow, Poland, 2007.

75. Poczta, W.; Średzińska, J.; Chenczke, M. Economic Situation of Dairy Farms in Identified Clusters of European Union Countries. Agriculture 2020, 10, 92. [CrossRef]

76. Burchi, F.; De Muro, P. From food availability to nutritional capabilities: Advancing food security analysis. Food Policy 2016, 60, 10-19. [CrossRef]

77. Mrówczyńska-Kamińska, A. Znaczenie rolnictwa w gospodarce narodowej w Polsce: Analiza makroekonomiczna i regionalna (The importance of agriculture in the Polish national economy: Macroeconomic and regional analysis). Zesz. Nauk. SGGW Probl. Rol. Świat. 2008, 5, 96-107.

78. Poczta, W.; Pawlak, K.; Dec, M. Globalny problem żywnościowy-typologia krajów według stopnia niedożywienia (Global nutrition problem-a typology of countries according to the rate of undernourishment). J. Law Econ. Sociol. 2008, 70, 191-204.

79. Baer-Nawrocka, A.; Markiewicz, N. Zróżnicowanie przestrzenne potencjału produkcyjnego rolnictwa w krajach Unii Europejskiej (The Spatial Differentiation of Agricultural Potential in EU Countries). Roczniki Nauk Rolniczych Seria G 2010, 97, 9-15.

80. Sapa, A. Rolnictwo krajów najsłabiej rozwiniętych-wybrane aspekty (Agriculture in the economies of the Least Developed Countries-selected aspects). Roczniki Ekonomiczne Kujawsko-Pomorskiej Szkoły Wyższej w Bydgoszczy 2012, 5, 149-159.

81. Brooks, J.; Matthews, A. Trade Dimensions of Food Security; Food, Agriculture and Fisheries Papers No. 77; OECD Publishing: Paris, France, 2015. [CrossRef]

82. Gohar, A.A.; Amer, S.A.; Ward, F.A. Irrigation infrastructure and water appropriation rules for food security. J. Hydrol. 2015, 520, 85-100. [CrossRef]

83. Misselhorn, A.; Hendriks, S.L. A systematic review of sub-national food insecurity research in South Africa: Missed opportunities for policy insights. PLOS ONE 2017, 12, e0182399. [CrossRef]

84. Sustainable Development Goals, Indicator 2.1.1-Prevalence of undernourishment. Available online: http: //www.fao.org/sustainable-development-goals/indicators/211/en/ (accessed on 20 June 2020). 
85. Food and Agriculture Organization of the United Nations Statistical Database. Capital Stock. Available online: http://www.fao.org/faostat/en/\#data/CS (accessed on 22 May 2020).

86. Food and Agriculture Organization of the United Nations Statistical Database. Value of Agricultural Production. Available online: http://www.fao.org/faostat/en/\#data/QV (accessed on 22 May 2020).

87. Sen, A.K. Ingredients of famine analysis: Availability and entitlements. Q. J. Econ. 1981, 96, $433-464$. [CrossRef]

88. Kolonko, J. Analiza Dyskryminacyjna i jej Zastosowania w Ekonomii (Discriminant Analysis and its Applications in Economics); Polish Scientific Publishers: Warsaw, Poland, 1980.

89. Food and Agriculture Organization of the United Nations Statistical Database. Macro Indicators. Available online: http://www.fao.org/faostat/en/\#data/MK (accessed on 22 May 2020).

90. Food and Agriculture Organization of the United Nations Statistical Database. Land Use. Available online: http://www.fao.org/faostat/en/\#data/RL (accessed on 22 May 2020).

91. Food and Agriculture Organization of the United Nations Statistical Database. Trade. Available online: http://www.fao.org/faostat/en/\#data/TP (accessed on 22 May 2020).

92. Baydildina, A.; Akshinbay, A.; Bayetova, M.; Mkrytichyan, L.; Haliepesova, A.; Ataev, A. Agricultural Policy Reforms and Food Security in Kazakhstan and Turkmenistan. Food Policy 2000, 25, 733-747. [CrossRef]

93. Løvendal, C.R.; Jakobsen, K.T.; Jacque, A. Food Prices and Food Security in Trinidad and Tobago; ESA Working Paper No. 07-27; Agricultural Development Economics Division: FAO, Rome, 2007.

94. Zhou, Z. Achieving Food Security in China: Past Three Decades and Beyond. China Agric. Econ. Rev. 2010, 2, 251-275. [CrossRef]

95. Urban In-Depth Emergency Food Security Assessment. Djibouti. WFP, July 2011. Available online: https://reliefweb.int/sites/reliefweb.int/files/resources/Full_Report_2172.pdf (accessed on 20 June 2020).

96. Bala, B.K.; Alias, E.F.; Arshad, F.M.; Noh, K.M.; Hadi, A.H.A. Modelling of Food Security in Malaysia. Simul. Model. Pract. Theory 2014, 47, 152-164. [CrossRef]

97. Darfour, B.; Rosentrater, K.A. Agriculture and Food Security in Ghana. In Proceedings of the Agricultural and Biosystems Engineering Conference Proceedings and Presentations 478, Orlando, FL, USA, 17-20 July 2016; Available online: https://lib.dr.iastate.edu/abe_eng_conf/478 (accessed on 20 June 2020).

98. Ramphul, N.; Nowbutsing, K.B.; Chittoo, H.B. An Analysis of Government Policies in Ensuring Food Security in Small Island Economies: A Case Study of Mauritius. IOSR J. Humanit. Soc. Sci. 2016, 21, 43-59. [CrossRef]

99. Huang, J.; Wei, W.; Cui, Q.; Xie, W. The Prospects for China's Food Security and Imports: Will China Starve the World Via Imports? J. Integr. Agric. 2017, 16, 2933-2944. [CrossRef]

100. Fiaz, S.; Noor, M.A.; Aldosri, F.O. Achieving food security in the Kingdom of Saudi Arabia through innovation: Potential role of agricultural extension. J. Saudi Soc. Agric. Sci. 2018, 17, 365-375. [CrossRef]

101. Pillay, D.P.K.; Manoj Kumar, T.K. Food Security in India: Evolution. Efforts Probl. Strateg. Anal. 2018, 42, 595-611. [CrossRef]

102. Gorman, T. From Food Crisis to Agrarian Crisis? Food Security Strategy and Rural Livelihoods in Vietnam. In Food Anxiety in Globalising Vietnam; Ehlert, J., Faltmann, N., Eds.; Palgrave Macmillan: Singapore, 2019.

103. Roy, D.; Sarker, D.D.; Sheheli, S. Food Security in Bangladesh: Insight from Available Literature. J. Nutr. Food Secur. 2019, 4, 66-75. [CrossRef]

104. Dithmer, J.; Abdulai, A. Does trade openness contribute to food security? A dynamic panel analysis. Food Policy 2017, 69, 218-230. [CrossRef]

105. Clapp, J. Food self-sufficiency: Making sense of it, and when it makes sense. Food Policy 2016, 66, 88-96. [CrossRef]

106. Fader, M.; Gerten, D.; Krause, M.; Lucht, W.; Cramer, W. Spatial decoupling of agricultural production and consumption: Quantifying dependences of countries on food imports due to domestic land and water constraints. Environ. Res. Lett. 2013, 8, 014046. [CrossRef]

107. Dec, M.; Pawlak, K.; Poczta, W. Determinanty sytuacji wyżywieniowej ludności świata (Determinants of the world nutrition situation). Village Agric. 2008, 2, 9-25.

108. Schultz, T.W. Transforming Traditional Agriculture; Yale University Press: New Haven, CT, USA, 1964.

109. Hayami, Y. Industrialization and agricultural productivity: An international comparative study. Dev. Econ. 1969, 7, 3-21. [CrossRef]

110. Hayami, Y.; Ruttan, V.W. Agricultural Development: An International Perspective; Johns Hopkins University Press: Baltimore, MD, USA, 1985. 
111. Stellmacher, T.; Kelboro, G. Family Farms, Agricultural Productivity, and the Terrain of Food (In)security in Ethiopia. Sustainability 2019, 11, 4981. [CrossRef]

112. Ogundari, K. The Paradigm of Agricultural Efficiency and its Implication on Food Security in Africa: What Does Meta-analysis Reveal? World Dev. 2014, 64, 690-702. [CrossRef]

113. Prus, P. The role of higher education in promoting sustainable agriculture. J. East Eur. Manag. Studies Corp. Soc. Responsib. Bus. Ethics Cent. Eastern Eur. 2019, 99-119. [CrossRef]

114. Prus, P. Sustainable farming production and its impact on the natural environment-case study based on a selected group of farmers. In Proceedings of the 8th International Scientific Conference Rural Development 2017: Bioeconomy Challenges, Aleksandras Stulginskis University, Kaunas, Lithuania, 23-24 November 2017; Raupeliene, A., Ed.; VDU Research Management System: Kaunas, Lithuania, 2017; pp. 1280-1285. [CrossRef]

115. Prus, P. Farmers' Opinions about the Prospects of Family Farming Development in Poland. In Proceedings of the 2018 International Conference "Economic Science for Rural Development" No. 47, Jelgava, Latvia, 9-11 May 2018; pp. 267-274. [CrossRef]

116. Nurkse, R. The Theory of Development and the Idea of Balanced Growth. In Developing the Underdeveloped Countries; Mountjoy, A.B., Ed.; Palgrave Macmillan: London, UK, 1971; pp. 115-128.

(C) 2020 by the authors. Licensee MDPI, Basel, Switzerland. This article is an open access article distributed under the terms and conditions of the Creative Commons Attribution (CC BY) license (http://creativecommons.org/licenses/by/4.0/). 